\title{
Global Civil Society, Animal Welfare, and Cultural Value: Analysis of Dogs Are Not Food Movement in Bali
}

\author{
P.R.K. Dewi , N.W.R. Priadarsini S. A.A.A.I Parameswari \\ Program Studi Ilmu HubunganInternasional, FISIP \\ Universitas Udayana \\ Denpasar, Bali \\ ratihkumaladewi@unud.ac.id \\ rainypriadarsini@gmail.com \\ prameswari.intan@gmail.com
}

\begin{abstract}
Bali got international attention after news and video released by Animals Australia that showedthe trade of dog meat in Bali and how these dogs were obtained by torture to be used as food. Animals Australia's investigation made the global civil society movement especially engaged in animal welfare increasingly massive and intense. Not only at the international level, but the participation of civil society in Bali regarding this issue is also increasingly intense. So that there is a movement from the public emerged to realize that dogs are not to be consumed through the Dogs are Not Food tagline. The social movements of global civil society are carried out institutionally in the form of NGOs (nongovernmental organizations) and non-institutionalized in the form of communities and individuals. The issue of animal welfare which is seen as a new issue is used as a basis for movement. This at once questioned whether the consumption of dog meat was in accordance with the cultural values adopted by the Balinese people. So that through this study the authors examined who the actors involved in the Dogs Are Not Food movement in Bali from 2017-2018 and analyzed the strategies implemented. The method used in conducting this research is a qualitative descriptive research method with data collection techniques through in-depth interviews and oral studies. The author used the new social movement theory, the concept of social movement strategy and the concept of cultural value. From the research obtained, the consumption of dog meat is also not in accordance with the customs and culture of Balinese people. The Dogs Are Not Food Movement in Bali involved global civil society who use each different framing and not all use a cultural approach in their movement strategy.
\end{abstract}

Keywords: Social Movement, Animal Welfare, Cultural Value, Dogs Are Not Food

\section{INTRODUCTION}

Nowadays the issue of dog meat trading and dogs slaughtering inhumanely has been the concern of the international community. This issue developed into an issue of international relations as the rapid emergence of various movements that built international attention on animal welfare issues and health security.

Dog meat trading for consumption is considered as not a natural thing because according to the provisions of the World Animal Health Organization (Office Internationale des Epizooties, OIE) and the Codex Alimentarius Commission (CAC), dogs are not included as slaughtered animals for human consumption. Dogs are categorized as pet animals. If dog meat is consumed by humans, according to the OIE and CAC it is considered to violate the principle of animal welfare (OIE Working Group on Animal Production Food Safety, n.d).

In Indonesia alone, there are about one million dogs killed every year (Dog Meat Free Indonesia. 2018). They were captured and stolen to be transported to all parts of Indonesia, in order to meet the demand for dog meat. Many family pets are stolen, and many are caught from the streets and villages to be illegally traded. This high number has become a polemic for Indonesia, while other Asian countries have begun to ban the trade in dog meat.

Bali as one of the tourism destinations in Indonesia which became the world's favorite was also highlighted after the news of the trade of dog meat satay on the beach around Seminyak was reported. In ABC news, some tourists unwittingly eat dog meat satay sold at a famous beach. This was obtained based on a four-month investigation 
conducted by the Animals Australia group, which found the fact that the traded dog meat was cruelly obtained from a number of dogs in Bali which isstolen, strangled, poisoned, shot and beaten to death (Animals Australia, 2017).

Animals Australia is an animal protection agency from Australia that is campaigning to stop the dog meat trade practices on the island of Bali. In its investigation, the institute found that the killing of dogs in Bali was in an alarming condition, at least 100,000 dogs were brutally slaughtered every year. This number is seven times more than the Yulin Festival, which is a famous dog meat festival in China (Animals Australia, 2017).

The news has a negative impact on the image of Bali tourism, especially the dog meat is traded to foreign tourists who do not know that it is dog meat. In addition, the fact that dog meat is obtained through dogs that are poisoned by cyanide is very dangerous to health due to the sale of dog meat because it is not examined and guaranteed to be healthy and has the potential to spread zoonotic diseases, especially rabies.

It is not only the international world that reacting to this news. This also reaps various responses from various circles in Bali, especially groups of animal lovers who are institutionalized in the form of non-governmental organizations, communities, and individual communities. Various protests and demands were filed to stop the trade in dog meat. It is important to end the trade in dog meat in Bali, especially to protect Bali's cultural and tourism industries. Various questions were asked whether the consumption of dog meat that not only endangers health is also in accordance with the culture of Balinese people. Considering the cultural value of Balinese society that is rich with the values of maintaining a balanced relationship that is carried out by humans with God, fellow human beings and nature including animals in it.

Based on this background, the authors are interested in researching movements in Bali that oppose the trade in dog meat in Bali in relation to animal welfare issues brought by International NonGovernmental Organizations (INGOs) and the cultural values of Balinese people themselves. The formulation of the problem raised by the researcher is based on this background, namely, how is the global civil society strategy in the Dogs Are Not Food movement in Bali?

The author used the theory of new social movements, the concept of social movement strategies and the concept of cultural values to analyze them. The concept of the social movement strategy concerning the mobilization and framing structure was used to analyze the strategies of Dogs are Not Foodsocial movements in Bali. How the mobilization structure of this movement is able to explain who the actors are involved in the movement both through formal structures and informal structures. Framing is also used to analyze how the strategy of this movement is to frame the issue of dog meat trade in Bali by linking it to certain elements such as values, attitudes, beliefs of the Balinese people and the media used in carrying out its strategy.

The discussion will begin with a review of the meaning of dogs for the people of Bali, trade in dog meat in relation to Balinese culture and animal welfare values, followed by a discussion of the strategy of global civil society in Bali in the movement of Dogs Are Not Food. This study uses a qualitative approach by collecting data through two methods. The first is through in-depth interviews that involve foundations / NGOs that reject the dog meat trade, animal lover communities, Balinese citizens, academics and artists. The second data collection technique is through a literature study.

\section{THE MEANING OF DOG FOR BALI COMMUNITIES}

Culturally, Balinese people in their daily lives cannot be separated from dogs. There is an expression from a Puri figure who said that "If there is no sound of a dog, its name is not Bali". In fact, this was written by a Mexican writer named Miguel Covarrubias. In a book published in 1933, Miguel Covarrubias once wrote the phrase "Bali would not be paradise without the dogs" (Benningshof, Yvette. 2011). This showed that dogs have long been part of the beauty of the island of Bali.

Balinese people are famous for their local wisdom, keeping dogs as house guards, released but will return to their owners. Old people always said that a house must have a dog if not, it's not a Balinese house. This showed that dogs are trusted as part of the family and the Balinese house is also the guard of the house (interview with RadityaPandet). They are nurtured to overcome silence at home, guard their employer's property, and there are those who believe as guardians of supernatural things. Especially in villages, there are still many houses that do not have a fence or door open just like that. So this dog that helps the Balinese in maintaining and protecting the community's house (interview with BAWA).

Dogs have many functions for Balinese people, it is not just ordinary pets but also as carers of homes, mates, and symbols of good deeds. The relationship between dogs and society in Bali is not only about practical use, but also concerns the belief primarily for Balinese Hindus. Basically, the Balinese people live based on the philosophy of Tri Hita Karana or the three causes of happiness, one of the points of which is to maintain good relations with essential nature.

Tri Hita Karana can be interpreted lexically as follows Tri means three, Hita means prosperity, and Karana means to cause. In essence, Tri Hita Karana contains the meaning of three causes of prosperity 
which are based on harmonious relationships consisting of:

1. Parahyangan is a harmonious relationship between humans and God Almighty.

2. Pawongan is a harmonious relationship between human beings.

3. Palemahan is a harmonious relationship between human beings and their natural environment (Babad Bali, n.d)

In Tri Hita Karana especially in the Palemahan point, it has been stated that humans should be able to foster good relations with the environment and its contents including animals (dogs) in it.

To realize harmony with the natural environment, especially animals, real actions that can be guided and implemented especially for Hindus are through the practice of the meaning of TumpekKandang ${ }^{I}$ andCaru $^{2} \quad$ (BhutaYadnya) with various levels. TumpekKandang is a holy day specifically for Balinese Hindus dedicated to animals, livestock and pets. Besides that, the purpose of the TumpekKandang ceremony is to maintain environmental harmony and contribute to the sustenance and happiness of humans. TumpekKandang as a commemoration of the holy day shows how Balinese Hindus view animals (including dogs) as creatures that are worthy of respect.

For Balinese people, dogs are also believed to be a symbol of purity so that dogs are made part of customs and even rituals. In certain rituals, the

${ }^{1}$ TumpekKandang or TumpekUye is a
holiday that held every Saniscara (Saturday)
KliwonWukuUye that arrives every 210 days. In
LontarSunarigamaujian
"SaniscaraKliwonUyepinakaprakertiningsarwasatoć"
means that day was indeed a milestone for preserving
all types of animals. The celebration of
TumpekKandang is a ritual procession to worship
animals. TumpekKandang is a religious ceremony to
worship the Pasupati Shiva, Ida Sang
HyangWidhiWasa (God Almighty) who has inspired
the crested animals' Cages essentially worship the
Pasupati Sang HyangSiwa, the manifestation of God
as the king of all Hindu beings. In
http://www.balishanti.id/tumpek-kandang/

${ }^{2}$ In the book SamhitaSwara mentioned, the meaning of the word caru is beautiful or harmonious. Why the ButhaYadnya ceremony is called caru. This is because one of ButhaYadnya goals is to harmonize human relations with the natural environment. In the book Sarasamuscaya 135 , it is stated that in order to guarantee the realization of the purpose of life in obtaining Dharma, Artha, Kama, and Moksha, first must do ButhaHita. ButhaHita means to transform the natural environment. In http://phdi.or.id/artikel/caru-adalah-memaknai-ruangdan-waktu
Balinese Hindu community uses a special dog as one of the offerings or "bantencaru", that is, bang bungkem dog. Bang Bungkem dog means a red dog on his body, but the mouth and tail snout are black. This is found in the lontarBhamaKertih. In this caru (purification ceremony) bang bungkem ceremony, all parts of the sacrificed dog must be used as a complement to caru. The meaning of this caru bang bungkem ceremony is to treat the evil spirits so that nature becomes more balanced and avoid various negative things (Interview with Ida PedandaPutuPeling).

Balinese also have a tradition of counting or reading the nature of dogs based on their shape. This method is used to find out the nature of the dog before someone takes care of it. This is mentioned in one manuscript, namely LontarCarcanAsu manuscript that is stored in the GedongKirtyaSingaraja manuscript museum. In this manuscript, the characteristics of Balinese dogs are explained. There are at least $31 \mathrm{dog}$ characteristics, all of them have different characters (BeritaBali.com, 2018). The existence of a dog in this manuscript showed that since ancient times, the ancient Balinese also made clear standards for Balinese dogs from their nature and function in human life.

Dogs are also said to be one animal that has a high loyalty to its master. Dog loyalty is also reported through religious stories namely YudistiraSwarga on the $17^{\text {th }}$ Parwa of Mahabharata. In the story Mahabarata narrated King Yudhistira with his four younger brothers, Bima, Arjuna, Nakula, Sadewa and his wife Drupadi decided to withdraw from the life of the world. They made a holy journey to the dwelling of the gods in heaven and the last to take part in the group is a dog. Before reaching the summit, one by one Yudhistira's brother fell. Only Yudhistira and his dog arrived at the gate of heaven.

When he wanted to enter heaven, Lord Indra forbade the dog to join Yudhistira but Yudhistira still wanted the dog to come into heaven. Yudhistira refused to go to heaven if his loyal dog did not join him. DewaIndra rejected the request on the grounds that the animal was not worthy of entering heaven. Yudhistira remained adamant about his position, so Yudhistira said that to leave any faithful being equal to hurting someone who asked for the protection of his master, such as killing a woman or expecting misfortune for a friend. As soon as Yudhistira stopped talking, the dog who had followed it from the beginning changed form to Sang Hyang Dharma, his father. Because of this Yudhistira was given his own privilege by being able to enter surge with his human body. Some interpret the dog in the story as a symbol of karma that is inseparable from the spirit. Where dogs can even enter swargaloka (heaven) because of their loyalty and honesty. Thus according to Balinese Hindu beliefs, dogs are believed to be carriers of people to heaven. 
This story is spreading in some communities until they believed and argued that dogs are animals that must be given respect and affection. This is in accordance with the teachings of Hinduism teaching to glorify living things. By killing a dog, it against the dog's life rights.

\section{ANIMAL WELFARE AND DOGS IN THE RELATIONSHIP WITH CULTURAL VALUE OF THE BALINESE PEOPLE}

The World Society for the Protection of Animals (WSPA) described in detail the use of these animals depending on their respective objectives. Animal utilization has to consider to Five Freedoms (WSPA, 2010). WSPA has the policy to categorize animals based on their benefits, namely:

1. Farm Animals are animals that are consumed such as cows, goats, chickens, etc.

2. Working Animals are animals that are used by energy such as horses, buffaloes, snowmobile pulling dogs, etc.

3. Companion Animals are pets that are cared for such as dogs, cats, other exotic animals

4. Laboratory Animals are animals that are used for research.

5. Genetic Manipulation and Genetic Engineering, are animals that have been manipulated genetically

6. Wild Animals are animals that live freely in nature such as orangutans, rhinos, etc.

7. Animals Used In Sport Or Entertainment, are animals that are used for sports and entertainment purposes such as horses/racing dogs, etc.

8. Marine Animals are animals that live in the sea

9. Fur and Trapping, namely the use of animal fur/skin and catching animals

10. Conservation, are animals that are endangered and maintained for conservation (Abrianto, 2009).

From the classification of these animals, it can be determined that the dog is a companion animal category and not an animal to be consumed as farm animals. So consumption of dog meat is not in accordance with the use of the dog itself. In addition, according to the World Health Organization (OIE) \& Codex Alimentarius Commission (CAC), consumption of dog meat is considered to violate the principle of animal welfare (OIE Working Group on Animal Production Food Safety, n.d). On the other hand, there are animal welfare issues due to the process of providing the dog's meat needs.

Animal welfare is an idea that began in the $18^{\text {th }}$ century. This appeared as a form of human closeness with animals. At the beginning of the $19^{\text {th }}$ century, the idea of the thought of protecting animals from suffering especially caused by human treatment was initiated in the form of regulations in North America and Europe on animal welfare. The animal rights protection movement developed rapidly globally as Richard Ryder introduced the term speciesism in 1970 (Ricard, Matthieu. 2017). Since then, civilian organizations have begun to oppose animal abuse and torture. In 1975, Peter Singer Animal Liberation, which became a milestone for the emergence of various animal rights organizations around the world (The Guardian, 2009).

Then the international world in 1979 (pioneered by North American and European Countries) tried to regulate aspects of animal welfare which refer to five principles (five freedoms), namely (1) free from hunger, thirst, and malnutrition; (2) free from fear and stress; (3) free from physical suffering and heat; (4) free from pain, injury and disease; and (5) free to express normal behavior. This is the reference frame for animal welfare.

The implementation of the Animal Welfare principles has been widely practiced in many countries. Whereas in Indonesia, Animal Welfare is a concept that is relatively new and not yet widely understood. This concept is difficult to translate where in general, the term "welfare" related to the life of humans, it is not animal. The application of the Animal Welfare concept in Indonesia is still not widely spread, but in other countries, this concept has underlain the emergence of many movements that describe global respect for the rights of animal life or animal rights. Many activists in various countries are so active in campaigning for these principles. Meanwhile, for developing countries including Indonesia, welfare is more a domain for improving the quality of human life. Unlike developed countries, people in developing countries are still struggling to achieve prosperity so that human welfare is considered a top priority. With the various dynamics that exist, both the level of education and the economy of the community, animal welfare is often not understood and tends to be ignored because it is considered only limited to theory and not yet applicable.

In the Indonesian context, animal welfare can be categorized as a new perspective and not yet widely understood. This concept is rather difficult to translate because prosperity has various meanings for everyone in Indonesia. But consciously or not, animals have entered into social values, culture, religion and in our daily life. In a culture, actually, the animal welfare embryo without realizing it already exists in the daily life of the Indonesian people. Prohibition of cockfighting, certain rituals before slaughtering animals, giving respect to certain types of animals and other activities are portraits of behavior in our society. The Indonesian people basically have an understanding of how to act so as not to hurt or commit cruelty to animals. This is reinforced by the values taught in the culture and religion adopted by the Indonesian people. 
Clyde Kluckhohn in Pelly (1994) defined cultural value as an organized general conception, which influences behavior related to nature, the position of humans in nature, the relationship of people to people and about desirable and undesirable things that may relate to the relationship of people to the environment and among human beings. Meanwhile, Sumaatmadja in Marpaung (2000) said that in the development, application of culture in life also developed values that are inherent in a society that regulates harmony and balance. These values are conceptualized as cultural values. Furthermore, starting from the above opinion, it can be said that every individual in carrying out his social activities is always based and guided by the value systems that exist and live in the community itself. This means that these values greatly affect human actions and behavior, both individually, in groups or in society as a whole about good, right, wrong, proper or inappropriate.

For the Hindu community itself, the dog is an animal that is considered abstinence for consumption. In the Nagarakertagama manuscript of 1365 , pigs are alluded to as one type of meat served at the Majapahit Palace, in addition to lamb, buffalo, chicken, cow, fish, and ducks. In addition, there are also several other types of meat that are not served to those who are obedient because of Hindu restrictions, although many are popular with ordinary people, such as frogs, worms, turtles, mice, dogs (Instagram @ sejarahbali).

Ida PadandaPutuPeling also explained,"According to the teachings of Hindu religion, there are several animals that can be consumed, for example, meat segara, pitik(duckies),kebo (Bull). While dogs are not included in animals that can be consumed. In the teachings of Hinduism, every mustached and 5fingered creature like a dog, monkey, etc. should not be consumed. Hinduism teachings do not allow us to eat dog meat. As stated earlier, usually 5-fingered and mustached animals can only be used for the Yadnya ceremony. "(Interview with Ida PadandaPutuPeling).

According to Mr. Bagus from BAWA, consumption of dog meat is not the culture of Balinese people but is carried by outsiders, but later in its development, not a few Balinese people who took part in consuming this dog meat. Apart from the trend, the majority of causes are public trust in certain myths, such as dog meat can cure asthma and other diseases. Myths that are not scientifically proven (interview with BAWA).

Responding to the dog meat trading in Bali, Parisadha Hindu Darma Indonesia also provided an overview of the behavior of Balinese people in general, called the PancaDresta which consists of the first SastraDresta, which is the dog's meaning according to literature where dogs are symbols of human good deeds and in "WanaprastaPurana" also mentioned that the dog is not worth eating. The second is PurwaDresta/Kuna Dresta which is the meaning of dogs according to the relics of ancient inscriptions. The third is LokaDresta which states that dogs are used as a means of ButhaYadnya, purification ceremony of the earth called Caru. The fourth is DesaDresta which states that there is not one village in Bali that treats dogs as daily consumption or makes it a daily menu. The last one is Kula Dresta which states that there is no custom of Balinese people who make dogs as a foodstuff (PHDI, 2018). From the studies based on the Dresta that apply in Bali, both SastraDresta, PurwaDresta, LokaDresta, Village Dresta or Kula Dresta, there is nothing to say that Balinese consume dog meat, even Balinese treat dogs as befits treating pets.

From these reviews, it was found that consumption and trade of dog meat were not in accordance with the cultural values of Balinese people.

\section{GLOBAL CIVIL SOCIETY STRATEGY IN DOGS ARE NOT FOOD MOVEMENT IN BALI}

The soaring demand for dog meat in several Indonesian cities, occurred just as other Asian countries began to leave the dog meat-eating culture. The New York Times reported on the high demand for dog meat in three cities in Indonesia, such as Yogyakarta, Bali and Jakarta (Cochrane, Joe. 2017). The Bali Animal Welfare Association estimates that every year there are around 70 thousand dogs killed and consumed in Bali (BAWA, 2014).

According to these conditions, the resistance to the dog trade is increasing in Indonesia, especially among the younger generation. Dogs Are Not Food (DANF) is a social movement aimed at eliminating dog meat consumption. This movement was initiated by several animal rights organizations in Indonesia. Starting in 2014, AFJ, GSI, and JAAN initiated a campaign that is currently a global campaign known as Dogs Are Not Food (DANF).

The social movement Dogs Are Not Food is framed by focusing on collective action and shared identity. The Dogs Are Not Food movement in Bali is basically to ban trade in dog meat. This movement was carried out by several NGOs, communities and even individuals with various campaign names both the same using the Dogs Are Not Food tagline and other taglines that have similar meaning, namely the prohibition of consuming dog meat.

To be able to analyze the strategy of the Dogs Are Not Food movement as part of the new social movement can be seen from the 2 characters, namely mobilization and framing structure (Doug, McCarthy, and Zald. 1996. p.7). The mobilization structure relates to the development of a network of support movements to support the success of achieving the goals of the social movement. Target oriented in the 
structure of recruitment mobilization or selection of target groups from various segments or layers of society which consists of 2 categories namely formal structure and informal structure (Doug, McCarthy, and Zald. 1996. p.354).Formal structures or macro mobilization structures include political parties, community organizations or social movement organizations. Through a formal structure, an organization can recruit members, socialize visions, overcome infiltration problems and form public opinion. While informal structures or micro mobilization structures include family units, networks of friends, volunteer associations, work units, and certain community communities.

While framing is a form of an individual's perspective on phenomena that are influenced by ideology within him. In other words, the frame determines an individual's attitude towards a phenomenon. According to Goffman (2002), frames in social movements are "interpretation schemes" that provide an individual's ability to identify a phenomenon that is happening around him. Framing determines how events are defined and determine whether an event is considered a social problem or not. Framing is not only fixated on individual settings but also groups. The framing process refers to the definition of David Snow interpreted as "Consciously strategic efforts by groups of people to form a shared understanding of the world and themselves that legitimizes and encourages collective action" (Benford and Snow, 2000).

Framing itself has certain elements such as values, attitudes, beliefs, and goals. The Framing Process is based on two important things. The first is the cultural contradiction and historical plot. According to this perspective, culture, ideology, and frames are important aspects of social movements, because the interaction between these three aspects becomes a symbol, "ammunition" or enthusiasm for social change (Benford and Snow, 2000). The culture here is a strategy to use generalized belief that exists in society as an ingredient in forming understanding by incorporating ideology promoted by a social movement organization.

The second is the framing process as a strategic activity. To reach a target group, movement actors need tools to run framing, namely the media. Social activists use coffee shops, cafes and meeting rooms as the media argue to socialize the issues so that community groups want to be involved in the social movement. Some even use street actions, long marches as part of the repertoire (choice of tactics and action strategies in explaining joint actions and other forms of protest).

There are several non-governmental organizations, communities and individual movements that will be examined here namely

\section{a. BAWA}

Bali Animal Welfare Association (BAWA) is an international non-profit organization engaged in animal welfare. BAWA is based in Bali, Indonesia and has a branch in Western Australia. BAWA, based in Bali, was founded by Janice Gardi since 2007 and has full-funding sources from donations and relies heavily on dedicated volunteer staffs. BAWA launched the "Dogs are not food" campaign with other NGOs namely Garuda Satwa Indonesia (GSI), Jakarta Animal Aid Network (JAAN), Animal Friend Jogja (AFJ) in Jakarta in 2014.

The issue of trading in dog meat is framed by linking it to the health and culture of the Balinese people. This was chosen because the research from BAWA found that Balinese who consume dog meat is mostly due to the belief in the myths of dog meat as a drug that is not scientifically proven. BAWA also relates to the belief or Balinese culture that sanctifies and highly purifies dog animals. The hope is that Balinese are easier to understand that dogs are not for consumption and further understand about animal welfare.

\section{b. BARC}

Bali Dog Adoption and Rehabilitation Center or BARC is an Australian / Indonesian non-profit animal organization. BARC was founded in 2006 by an Australian citizen named Linda Buller. In 2017, BARC made a move to stop the trade in dog meat. However, because there is no authority from the government, BARC cannot carry out the movement door to door. BARC had been facing Bendesa and the village heads, but they were asking for a letter from the government.

In carrying out its movement, BARC facilitates the issue of trading dogs in Bali by distributing the tagline "Eating dog meat is NOT Balinese tradition, it is also NOT a cheaper food option" on its website. BARC uses the basis of culture to frame its movements. This showed that BARC framed the issue of the trade in dog meat in Bali by using a cultural approach to the Balinese people, namely linking it with certain elements such as values, attitudes, beliefs of Balinese people. This is part of the BARC strategy in carrying out its movement.

\section{c. Yayasan Seva Bhuana}

The SevaBhuana Foundation or YSB is a local Balinese foundation engaged in animal welfare. YSB was formed with the awareness of its founders to create sustainable education programs for young people. YSB's mission is "Increasing public awareness of the importance of harmonious relationships with animals and nature". In carrying out its movement, YSB relates it to the cultural value of Balinese society.

In addition, to framing the issue of dog meat trade through culture, YSB framed the issue of dog meat trade with tourism. Tourism is the main source of economy for Balinese people. There was an incident of foreign tourists who accidentally ate dog meat on Kuta beach because they did not understand the term RW and the need (demand) of migrant 
people in Bali who often consume dog meat, which is contrary to Balinese culture. Trading dog meat can damage tourism's image and disrupt the economy of Balinese people. As one of the largest foreign exchange for the tourism sector, the image or image of Bali tourism must be maintained and maintained.

The interesting part is that the framing process carried out by YSB is through art and movie screening with film media. The film is seen as a very effective medium because the human tendency is easier to capture visually.

\section{d. Stop BuangAnjing (Stop Dispose of Dogs)}

Stop BuangAnjing was established in July 2016, by I. B. G. Nara Digda and DewaWidana. Stop BuangAnjing or commonly referred to as SBA, is not a community or foundation but a social movement in the form of persuasive campaigns. SBA has a nickname for its members by calling it a "Dog Friend". Although the main mission of stopping dogs is to treat rabies in dogs on the streets, the ban on dog meat trade is also on their agenda.

Because it is based in Bali, SBA in carrying out its movement framing the issue by carrying out the values of Balinese Hindu culture, in particular, relating to non-ethical beliefs because of the SBA research shows that Balinese people like things that are related toniskala (Mystical things) and tend to believe it. Like the belief that dogs are sacred for caru (purification ceremony) and not for eating, besides the cultural values of Balinese people are taken from the Story of Swargarohanaparwa which is the last book of the eighteenth series of the Mahabrata epics.

\section{e. Pet Learning Organization}

Pet-learning Organization is a student organization in the Faculty of Veterinary, Udayana University. The organization was founded in 2007. At present, this organization has 105 students. This organization is a place for students who have an interest in learning about maintenance and understanding of pets, one of which is a dog. PLO also voiced stop eating dog meat. The main focus was to the community. But in carrying out its movement the PLO did not frame it with the issue of Balinese culture but more towards health.

\section{f. Individual rescuer}

From the results of interviews with 4 rescuers, it was obtained data that most rescuers move with framing in general, which relates to animal welfare issues without linking to Balinese culture. This movement is mostly carried out individually or with a mobilization structure in collaboration with other NGOs. Only Ms. Desy Chen is engaged in framing that relates to cultural and health issues. Currently, Ms. Desy also collaborates with an alliance that aims to find and make laws that protect animals from the violence of dogs in particular. The group is called
GAKHDI (Gerakan Anti KekerasanHewanDomestic Indonesia or Indonesian Domestic Animal AntiViolence Movement) which is a combination of an alliance of animal lovers throughout Indonesia. The thing that is championed through GAKHDI is the rights of domestic animals. Such as the recent phenomena are violence and neglect, dog meat trade, and the revision of the Criminal Code Law with a new bill to clarify and regulate in more detail the domestic violence against domestic animals.

\section{g. Academics}

The academician who was the speaker in this study was Uru Yogi AntariTirtaYasa, S.Sn.,M.Sn, who is a Lecturer at ISI Denpasar majoring in Film. She is an animal welfare observer and since 2012 has become the SevaBhuana Foundation Volunteer (formerly called Animal Shanti). According to her, education is the most appropriate way to build public awareness of the problem of dog meat trading. Especially for Balinese people, the cultural approach is seen as the most effective framing because it is easily understood by the community compared to using animal welfare framing. Film media is also seen as a medium in an effective framing process because it immediately displays what the picture looks like. This also remembers humans more easily remembering things that are seen visually.

\section{h. Artist}

The artist who is the speaker is RadityaPandet. $\mathrm{He}$ is the filmmaker of Sang Asu and UlamAsu. The film, UlamAsu, is an investigative based documentary film that uses the framing of Balinese people's health and culture. Balinese people are not dog meat eaters. Pandet agreed with the speaker in his film, the cultural observer CokSawitri. CokSawitri said that consumption of dog meat was not the culture of Balinese people, not in accordance with religious teachings. Even the sin is worse than abortion or called Burnaha. So in Balinese Hinduism, consumption of dog meat is worse than Burnaha. According to her, the only thing that can be used here is culture and religion because Indonesians are most afraid of sin, believe in heaven and hell. 
So, it can be summarized through the table below:

\begin{tabular}{|c|c|c|c|c|}
\hline TYPE & NAME & $\begin{array}{l}\text { MOBILIZATION } \\
\text { STRUCTURE }\end{array}$ & FRAMING & MEDIA \\
\hline \multirow{4}{*}{$\begin{array}{l}\text { Non- } \\
\text { Governmental } \\
\text { Organizations } \\
\text { (NGOs) / } \\
\text { Foundation }\end{array}$} & $\begin{array}{l}\text { Bali Animal } \\
\text { Welfare } \\
\text { Association } \\
\text { (BAWA) }\end{array}$ & $\begin{array}{l}\text { Formal structure in } \\
\text { collaboration with } \\
\text { community organizations } \\
\text { (NGO/ non- } \\
\text { governmental } \\
\text { organization) } \\
\text {-Garuda Satwa Indonesia } \\
\text { (GSI) } \\
\text { - Jakarta Animal Aid } \\
\text { Network (JAAN) } \\
\text { - Animal Friend Jogja } \\
\text { (AFJ). }\end{array}$ & $\begin{array}{l}\text { Educate with the } \\
\text { culture of Balinese } \\
\text { people }\end{array}$ & $\begin{array}{l}\text { Direct socialization } \\
\text { and social } \\
\text { media(Facebook, } \\
\text { Instagram, and } \\
\text { Twitter) }\end{array}$ \\
\hline & BARC & $\begin{array}{l}\text { Formal structure, } \\
\text { collaboration } \\
\text { withInternationalNon- } \\
\text { Governmental } \\
\text { Organization/INGO) } \\
\text { such as Animals } \\
\text { Australia andcompanies } \\
\text { that dofunding to BARC }\end{array}$ & $\begin{array}{l}\text { Cultural Approach } \\
\text { through Balinese } \\
\text { society related to } \\
\text { certain elements } \\
\text { such as cultural } \\
\text { values, behaviors, } \\
\text { and belief of } \\
\text { Balinese society. }\end{array}$ & $\begin{array}{l}\text { Long March, } \\
\text { Internet through } \\
\text { BARC's official } \\
\text { website } \\
\text { https://barc4balidog } \\
\text { s.org.au/, and } \\
\text { alsosocial media } \\
\text { (Instagram and } \\
\text { Facebook) }\end{array}$ \\
\hline & $\begin{array}{l}\text { Yayasan Seva } \\
\text { Bhuana }\end{array}$ & $\begin{array}{l}\text { Formal Structure through } \\
\text { collaboration with } \\
\text { NGOsuch as Bali Pet } \\
\text { Crusaders, YayasanSeva } \\
\text { Bhuana with IKAL } \\
\text { BPPT, Animal Shanti } \\
\text { and Animals Australia } \\
\text { Org. } \\
\text { Informal structure, } \\
\text { Collaboration with } \\
\text { volunteers, individuals, } \\
\text { young generation and } \\
\text { artist }\end{array}$ & $\begin{array}{l}\text { Balinese culture } \\
\text { and tourism }\end{array}$ & $\begin{array}{l}\text { Framing process by } \\
\text { doing direct } \\
\text { socialization to } \\
\text { school, art and } \\
\text { movie screening } \\
\text { with a film titled } \\
\text { Enslaved, Sang } \\
\text { Asuand Ulam Asu } \\
\text { also social media } \\
\text { (Facebook) }\end{array}$ \\
\hline & $\begin{array}{l}\text { Pet Learning } \\
\text { Organization }\end{array}$ & $\begin{array}{l}\text { Informal structure } \\
\text { collaborateswith dog } \\
\text { lover community such as } \\
\text { pet Bali, golden Bali, } \\
\text { Kintamani Bali, herder, } \\
\text { AGJ, andPitbull. }\end{array}$ & Health & $\begin{array}{l}\text { Education through } \\
\text { routine events such } \\
\text { as WPD or World } \\
\text { Petrinary day, long } \\
\text { March in Renon, } \\
\text { oration with } \\
\text { influenced poster, } \\
\text { fun activity, dog } \\
\text { show competition. }\end{array}$ \\
\hline \multirow[t]{2}{*}{$\begin{array}{l}\text { Other Social } \\
\text { Movements }\end{array}$} & $\begin{array}{l}\text { Stop Buang } \\
\text { Anjing }\end{array}$ & $\begin{array}{l}\text { Formal structure } \\
\text { collaborates } \\
\text { withINGOlike BARC, } \\
\text { BAWA } \\
\text { Formal structures } \\
\text { collaborate with dog } \\
\text { lover community such as } \\
\text { BPC, Walfarian Bali, and } \\
\text { Ms. Tio RUSS and } \\
\text { individual rescuer. }\end{array}$ & $\begin{array}{l}\text { Culture framing } \\
\text { emphasizes the } \\
\text { value ofHindu } \\
\text { culture and } \\
\text { Balinese beliefs. }\end{array}$ & $\begin{array}{l}\text { Direct socialization } \\
\text { by using a graphic, } \\
\text { pictures, booklet, } \\
\text { and also social } \\
\text { media. (Facebook, } \\
\text { Instagram, Twitter) }\end{array}$ \\
\hline & $\begin{array}{l}\text { Desy Chen } \\
\text { (Rescuer) }\end{array}$ & $\begin{array}{l}\text { Formal structure } \\
\text { collaborates } \\
\text { withYayasanSevaBhuana }\end{array}$ & Health and culture & $\begin{array}{l}\text { Direct socialization } \\
\text { through social } \\
\text { media named "Bali }\end{array}$ \\
\hline
\end{tabular}




\begin{tabular}{|c|c|c|c|c|}
\hline \multirow[t]{6}{*}{ Individual } & & $\begin{array}{l}\text {, JAAN and Garda } \\
\text { Satwa. } \\
\text { Informal structure } \\
\text { collaborates withGerakan } \\
\text { Anti } \\
\text { KekerasanHewanDomest } \\
\text { ic Indonesia }\end{array}$ & & Dog Lover". \\
\hline & $\begin{array}{l}\text { - I Dewa Ayu } \\
\text { Putu Sri } \\
\text { Kusuma Dewi } \\
\text { (Rescuer) }\end{array}$ & $\begin{array}{l}\text { Formal structure with } \\
\text { NGO Bali Petcrusider. }\end{array}$ & Animal welfare & $\begin{array}{l}\text { Poster and social } \\
\text { media(Facebook })\end{array}$ \\
\hline & $\begin{array}{l}\text { Desak Putu Ary } \\
\text { Dwi Parwati } \\
\text { (Rescuer) }\end{array}$ & Individually & Animal welfare & $\begin{array}{l}\text { Social media } \\
\text { (Facebook and } I \\
\text { nstagram) }\end{array}$ \\
\hline & $\begin{array}{l}\text { Phebe Natalia } \\
\text { D.K }\end{array}$ & $\begin{array}{l}\text { Formal structure } \\
\text { collaborates with NGO } \\
\text { Animal Defender }\end{array}$ & Animal welfare & $\begin{array}{l}\text { Social media and } \\
\text { direct socialization }\end{array}$ \\
\hline & $\begin{array}{l}\text { Desak Putu } \\
\text { Yogi Antari } \\
\text { Tirta Yasa, } \\
\text { S.Sn., } \\
\text { M.Sn.(Academi } \\
\text { cs and } \\
\text { Volunteers) }\end{array}$ & $\begin{array}{l}\text { Formal structure with } \\
\text { YSB, JAAN and Dogs } \\
\text { Are Not Food Indonesia } \\
\text { community. } \\
\text { Informal structure with } \\
\text { an artist (filmmaker) and } \\
\text { volunteerfrom other } \\
\text { community and } \\
\text { organization. }\end{array}$ & $\begin{array}{l}\text { Education by using } \\
\text { culture and animal } \\
\text { welfare framing }\end{array}$ & $\begin{array}{l}\text { Socialization to } \\
\text { schools, movie } \\
\text { screening, } \\
\text { andanimal } \\
\text { discussion }\end{array}$ \\
\hline & $\begin{array}{l}\text { Raditya Pandet } \\
\text { (Artist/ } \\
\text { filmmaker) }\end{array}$ & $\begin{array}{l}\text { Formal structure } \\
\text { collaborates } \\
\text { withYayasanSevaBhuana } \\
\text {, JAAN, and Stop } \\
\text { BuangAnjing. } \\
\text { Informal structure with } \\
\text { other artists }\end{array}$ & $\begin{array}{l}\text { The culture of } \\
\text { Balinese society }\end{array}$ & $\begin{array}{l}\text { Film and doing the } \\
\text { march. }\end{array}$ \\
\hline
\end{tabular}

\section{CONCLUSION}

Consumption of dog meat in the perspective of Balinese people is not a tradition and is stated not in accordance with the customs and culture of Balinese people. The act of consuming dog meat is contrary to the philosophy of Tri Hita Karana, that humans should be expected to be able to foster a good relationship between the environment and its contents, including dogs. This is also not in accordance with the practice of the meaning of the TumpekKandang holiday and the belief of the Balinese Hindu community that the dog is a symbol of purity so that dogs are made part of the customs and even rituals that are offerings or "banten"caru (purification ceremony), namely bang bungkem dogs. This is found in theBhamaKertih manuscript. Dogs are also said to be one animal that has a high loyalty to its master. The dog's loyalty is also reported through the religious story of YudistiraSwarga in the $17^{\text {th }}$ Parwa of the Mahabharata.

While sociologically, the Hindu community in Bali does not consume dog meat. This is also affirmed by Parisadha Hindu Darma Indonesia which provides an overview of the behavior of Balinese people in general, called PancaDresta. From this study, the consumption of dog meat is not in accordance with the daily life of people in Bali.

The Dogs Are Not Food Movement in Bali involved global civil society consisting of nongovernmental organizations namely Bali Animal Welfare Association (BAWA), Bali Adoption SevaBhuana Foundation's Rehab Center (BARC) and Pet Learning Organization other social movements namely Stop BuangAnjing and individuals namely individual rescuers, academics and artists. The framing movement of Dogs Is Not Food in Bali varies depending on the global civil society actors themselves. Not all actors use framing of Balinese culture in carrying out their movements. From this research, the actors who carry out the movement with framing issues that relate to culture are BAWA, BARC, SevaBhuana Foundation, and Stop BuangAnjing and individual movements namely academics and artists. Whereas individual rescuers that framing the contentsvary but most of them do not use culture framing in their movements. A rescuer who used the issue of culture in the framing of the movement was only Mrs. Desy Chen. 


\section{REFERENCES}

[1] Abrianto, 2009. Kesejahteraan Hewan. in http://duniasapi.com/kesejahteraanhewanaccessed on May 16th, 2018

[2] Animals in Australia. 2017.Animals Australia's shocking investigation into Bali's dog meat trade exposed on $A B C \quad 7.30$ in http://www.animalsaustralia.org/features/dogmeat-investigation-bali-abc-730.phpaccessed on January 10th, 2018.

[3] Babad Bali. n.d. Tri Hita Karana dalam Agama Hindu in http://www.babadbali.com/ canangsari/trihitakarana.htmaccessed on May 8th, 2018.

[4] BAWA. 2014. Please Know The Law \& Use The Law: BAWA. In http://bawabali.com/pleaseknow-the-law-use-the-law-bawa/accessed on February 2nd, 2018.

[5] Benford, Robert D., and Snow, David A. 2000. Framing Processes and Social Movements: An Overview and Assessment. Annual Review of Sociology Vol. 26 (2000), pp. 611-639

[6] Benningshof, Yvette. 2011. Bali: Island Of The Dogs in https://latitudes.nu/bali-island-of-thedogs/accessed on June 2nd, 2018.

[7] BeritaBali.com. 2018. Mengenal Sifat dan Karakter Dari Anjing in https://beritabali.com/read/ 2018/04/11/201804110001/Mengenal-Sifatdan-Karakter-Dari-Anjing.html?fb comment

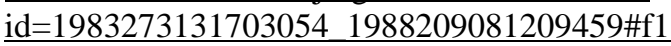
d1747af150c34accessed on May 12th 2018.

[8] Cochrane, Joe. 2017. Indonesians' Taste for Dog Meat Is Growing, Even as Others Shun It. New York Times in https://www.nytimes.com/2017/03/25/world/asi a/indonesia-dog-meat.htmlaccessed on May 18th, 2018.

[9] Dog Meat Free Indonesia. 2018. The Dog Meat Trade and Rabies Transmission in https://www.dogmeatfreeindonesia.org/issues/d og-meat-tradeaccessed on January 12th, 2018.

[10] Doug, McCarthy, and Zald, 1996, Comparative Perspectiveson Social Movement: Political Opportunities, Mobilizing Structures, and Cultural Framing, Cambridge University Press, UK, New York.

[11] Goffman, Erving, Frame Analysis: An Essay on the Organization of Experience, Penguin, Harmondsworth, 1974.

[12] Marpaung, Parlindungan. 2000. Analisis Perubahan Nilai Sosial Budaya dan Pengaruhnya Terhadap Pembangunan Wilayah di Kecamatan Pangururan Kabupaten Tapanuli Utara. TesisTidak Diterbitkan. Medan: Program PascaSarjana USU.

[13] OIE Working Group on Animal Production Food Safety, n.d. Cooperation Between The
Codex Alimentarius Commission And The Oie On Food Safety Throughout The Food Chain in https://www.oie.int/doc/ged/D3658.PDFaccesse d on May 17th, 2018.

[14] Pelly and Menanti, 1994. Teori-Teori Sosial Budaya. Jakarta :Direktorat Jendral pendidikanTinggi DepartemenPendidikan danKebudayaan.

[15] PHDI. 2018. Panca Dresta Parisadha Hindu Darma Indonesia. PHDI Bali

[16] Ricard, Matthieu. 2017. Beyond Species-ism. In https://www.huffingtonpost.com/ entry/beyondspeciesism_us 592da8f4e4b07c4c731385c6accessed on May 15th 2018.

[17] The Guardian. 2009.A life in philosophy: Peter Singer. In https://www.theguardian.com/books /2009/may/23/peter-singer-philosophy-animalwelfareaccessed on May 17th, 2018

[18] WSPA. 2010. Animal Welfare and Rabies Control. WSPA Annual General Meeting June 2010 